\title{
INTERPRETASI HAKIM TENTANG ANAK DI LUAR KAWIN PASCA PUTUSAN MAHKAMAH KONSTITUSI NOMOR 46/PUU-VIII/2010 TENTANG PENGUJIAN UU NOMOR 1 TAHUN 1974 TENTANG PERKAWINAN (Studi di Pengadilan Agama Purwokerto)
}

\author{
Mukhamad Farid \\ Magister IImu Hukum Fakultas Hukum Universitas Jenderal Soedirman
}

\begin{abstract}
The religious court judges interpretation of the child outside the marriage after the Constitutional Court Decision No. 46 / PUU-VIII / 2010 on the review of Act 1 of 1974 in the Religious Navan and How the legal consequences of the Constitutional Court Decision No. 46 / PUU-VIII / 2010 on the review of Act No. 1 In 1974 in the Religious Purwokerto. This research method approach using Method approach taken in this study is a combination of socio-juridical field that uses primary data and secondary data from interviews with informants. Legal consequences of the Constitutional Court Decision No. 46 / PUU-VIII / 2010 on the testing of Law No. 1 In 1974 the Religious Court of Navan, which is stated in the decision of the Decision No. 1306 / Pdt.G / 2012 / PA.Pwt, that the reason behind the law to assert that illegitimate children were entitled to legal protection. The panel of judges to interpret the law or the interpretation of such cases and legal considerations have encouraged the necessity of providing protection and legal certainty to the status of a child born and the rights available to it, including against children born even though the validity of marriage is still disputed.
\end{abstract}

Keywords: child outside marriage, interpretation and legal consequences.

\begin{abstract}
ABSTRAK
Interpretasi hakim Pengadilan Agama tentang anak di luar kawin pasca Putusan Mahkamah Konstitusi Nomor 46/PUU-VIII/2010 tentang pengujian UU No.1 Tahun 1974 di Pengadilan Agama Purwokerto dan Bagaimanakah konsekuensi hukum terhadap Putusan Mahkamah Konstitusi Nomor 46/PUU-VIII/2010 tentang pengujian UU No. 1 Tahun 1974 di Pengadilan Agama Purwokerto. Metode pendekatan adalah yuridis sosiologis merupakan gabungan antara lapangan yang menggunakan data primer dan data sekunder berupa wawancara dengan informan. Konsekuensi hukum terhadap Putusan Mahkamah Konstitusi Nomor 46/PUU-VIII/2010 tentang pengujian UU No. 1 Tahun 1974 di Pengadilan Agama Purwokerto, yaitu tertuang dalam putusan Putusan Nomor 1306/Pdt.G/2012/PA.Pwt, bahwa alasan hukum yang melatar belakangi untuk menegaskan bahwa anak luar kawin pun berhak mendapat perlindungan hukum. Majelis hakim melakukan intepretasi ataupun penafsiran hukum dalam kasus tersebut dan mempunyai pertimbangan hukum yang mendorong adanya keharusan memberi perlindungan dan kepastian hukum yang adil terhadap status seorang anak yang dilahirkan dan hak-hak yang ada padanya, termasuk terhadap anak yang dilahirkan meskipun keabsahan perkawinannya masih disengketakan.
\end{abstract}

Kata kunci : anak luar kawin, interpretasi dan konsekuensi hukum.

\section{PENDAHULUAN}

Mahkamah Konstitusi sesuai dengan kewenangan yang diberikan dalam UUD 1945 Pasal 24C mempunyai wewenang untuk melakukan pengujian Undang-undang terhadap UUD 1945.

Putusan Mahkamah Konstitusi yang mengabulkan uji materiil Undang-undang Perkawinan (UU No.1

Tahun 1974) yang diajukan Hj. Aisyah Mochtar 
alias Machica binti $\mathrm{H}$. Mochtar Ibrahim yang meminta putranya Muhammad lqbal Ramadhan bin Drs. Moerdiono agar diakui sebagai anak almarhum Drs. Moerdiono mantan Menteri Sekretaris Negara di era Soeharto memicu perseteruan antara dirinya dengan keluarga almarhum Drs.Moerdiono. ${ }^{1}$

Amanat dari konstitusi tersebut, yang salah satunya memberikan kesempatan kepada Mahkamah Konstitusi untuk melakukan terobosan dan perubahan atas Pasal 43 ayat (1) Undang-undang Nomor 1 Tahun 1974 tentang Perkawinan. Sesuai dengan prinsip erga omnes maka, putusan Mahkamah Konstitusi Nomor 46/PUU-VIII/2010 tanggal 17 Februari 2012 bersifat mengikat kepada publik dan tidak hanya pada para pihak yang berperkara di persidangan Mahkamah Konstitusi, sehingga tidak mengherankan lahirnya pro dan kontra atas putusan Mahkamah Konstitusi tersebut, yang memberikan pengakuan anak luar kawin terhadap hubungannya dengan biologisnya. $^{2}$

Pasal 43 ayat (1) Undang-undang Nomor 1 Tahun 1974 tentang Perkawinan diatur bahwa "Anak yang dilahirkan di luar perkawinan hanya mempunyai hubungan perdata dengan ibunya dan keluarga ibunya". Pada 17 Februari 2012, Mahkamah Konstitusi menyatakan Pasal 43 ayat (1) Undang-undang Nomor 1 Tahun 1974 tentang Perkawinan tersebut inkonstitusional bersyarat.

Habiburrahman, Anak Luar Nikah Dalam Putusan Mahkamah Konstitusi, Jurnal Mimbar Hukum dan Peradilan, diterbitkan oleh Pusat Pengembangan Hukum Islam dan Masyarakat Madani (PPHIMM), Edisi No.75, Jakarta, 2012, hal 34.

2 Syafran Sofyan, Analisis Hukum Putusan Mahkamah Konstitusi No. 46/PUU-VIII/2010 tentang Status Anak Luar Kawin, tersedia di website http://www.goocom, diakses tanggal 1 Oktober 2013, hal 3.
Dalam amar putusannya, Mahkamah Konstitusi menyatakan Pasal 43 ayat (1) UU Perkawinan tersebut, bertentangan dengan UUD 1945 sepanjang dimaknai menghilangkan hubungan dengan laki-laki yang dapat dibuktikan melalui ilmu pengetahuan dan teknologi dan/atau alat bukti lain ternyata mempunyai hubungan darah sebagai ayahnya.

Mahkamah Konstitusi memberikan keputusan mengabulkan sebagian permohonan para pemohon. Permohonan Pasal 2 ayat (2) Undangundang Nomor 1 Tahun 1974 tentang Perkawinan, tidak dikabulkan sebab perkawinan yang dicatatkan adalah untuk mencapai tertib administrasi, pencatatan secara administratif yang dilakukan negara dimaksudkan agar perkawinan, sebagai perbuatan hukum penting dalam kehidupan yang dilakukan oleh yang bersangkutan, yang berimplikasi terjadinya akibat hukum yang sangat luas, di kemudian hari dapat dibuktikan dengan bukti yang sempurna dengan suatu akta otentik, sehingga perlindungan dan pelayanan oleh negara terkait dengan hak-hak yang timbul dari suatu perkawinan dapat terselenggara secara tertib dan efisien. ${ }^{3}$

Putusan Mahkamah Konstitusi No. 46/PUUVIII/2010, sampai saat ini menyisakan persoalan yang belum tuntas dan terus menjadi perdebatan panjang dari berbagai elemen masyarakat Indonesia, mulai dari ahli hukum, baik praktisi maupun

\footnotetext{
Chatib Rasyid, Anak Lahir di Luar Nikah (Secara Hukum) Berbeda Dengan Anak Hasil Zina,( Putusan Mahkamah Konstitusi No. 46/PUU-VIII/2010), Jurnal Mimbar Hukum dan Peradilan, diterbitkan oleh Pusat Pengembangan Hukum Islam dan Masyarakat Madani (PPHIMM), Edisi No.75, Jakarta, 2012, hal 184.
} 
akademisi, para alim ulama, para pemerhati hak asasi manusia dan perlindungan Anak Indonesia bahkan sampai kepada masyarakat awam, nampaknya semua menyuarakan isi hatinya dari berbagai sudut pandang.

Dalam hal ini, hakim juga mempunyai interprestasi atau penafsiran hukum tersendiri terhadap putusan Mahkamah Konstitusi No. 46/PUU-VIII/2010, tentang anak di luar kawin. Interpretasi hukum merupakan salah satu metode yang dapat menjembatani antara peraturan perundang-undangan yang statis dengan fakta sosial dan perubahan zaman yang dinamis dan selalu berubah.

\section{RUMUSAN MASALAH}

Melihat pada latarbelakang permasalahan yang telah diurai diaras, dirumuskan perumusan masalah sebagai berikut: Pertama, Bagaimanakan interpretasi hakim pengadilan agama tentang anak diluar kawin pasca Putusan Mahkamah Konstitusi No. 46/PUU-VII/2010 tentang Pengujian UU No. 1 Tahun 1974 di Pengadilan Agama Purwokerto; Kedua, Bagaimana Konsekuensi hukum terhadap Putusan Mahkamah Konstitusi Nomor 46/PUUVIII/2010 tentang pengujian UU No. 1 Tahun 1974 di Pengadilan Agama Purwokerto

\section{METODE PENELITIAN}

Metode pendekatan yang dilakukan dalam penelitian ini adalah Yuridis Sosiologis merupakan gabungan antara lapangan yang menggunakan data sekunder dan data primer berupa wawancara dengan informan. Menurut pendapatnya Bambang
Sunggono ${ }^{4}$, bahwa penelitian sosiologis berusaha menelaah kaidah-kaidah hukum yang berlaku di masyarakat. Hukum tidak dimaknai sebagai kaidah-kaidah normatif yang eksistensinya berada secara ekslusif di dalam sistem legitimasi yang formal, melainkan sebagai gejala empiris teramati di pengalaman. ${ }^{5}$ Penelitian ini bersifat deskritif analitis. Data yang diperoleh akan disajikan dalam bentuk teks naratif dan matriks data. Analisis Data dilakukan dengan metode kualitatif, yaitu analisis isi (Content analysis method).

\section{PEMBAHASAN}

Interpretasi hakim Pengadilan Agama tentang anak di luar kawin pasca Putusan Mahkamah Konstitusi Nomor 46/PUU-VIII/2010 tentang pengujian UU No.1 Tahun 1974 di Pengadilan Agama Purwokerto

Negara berdasarkan hukum ditandai oleh beberapa asas, antara lain asas bahwa semua perbuatan atau tindakan pemerintahan atau negara harus didasarkan pada ketentuan hukum tertentu yang sudah ada sebelum perbuatan atau tindakan itu dilakukan. Campur tangan atas hak dan kebebasan seseorang atau kelompok masyarakat hanya dapat dilakukan berdasarkan aturan-aturan hukum tertentu. Asas ini lazim disebut asas legalitas (legaliteits beginse/). Untuk memungkinkan kepastian perwujudan asas legalitas ini, harus dibuat berbagai peraturan hukum antara lain peraturan perundang-undangan.

Menurut Azhary, bahwa: 
Secara formal istilah negara hukum dapat disamakan dengan rechtsstaat ataupun rule of law mengingat ketiga istilah tersebut mempunyai arah yang sama, yaitu mencegah kekuasaan absolut demi pengakuan dan perlindungan hak asasi. Perbedaannya terletak pada arti materiil atau isi dari ketiga istilah tersebut yang disebabkan oleh latar-belakang sejarah dan pandangan hidup suatu bangsa. ${ }^{6}$

Dasar pijakan bahwa negara Indonesia adalah negara hukum tertuang pada Pasal 1 ayat (3) UUD 1945, yang menyebutkan bahwa "Negara Indonesia adalah Negara Hukum”. Dimasukkannya ketentuan ini ke dalam bagian Pasal UUD 1945 menunjukkan semakin kuatnya dasar hukum serta menjadi amanat negara, bahwa negara Indonesia adalah dan harus merupakan negara hukum.

Mahkamah Konstitusi adalah lembaga tinggi negara dalam sistem ketatanegaraan Indonesia yang merupakan pemegang kekuasaan kehakiman bersama-sama dengan Mahkamah Agung. Pasal 24 ayat (2) Undang-Undang Dasar Negara Republik Indonesia Tahun 1945 menyatakan, kekuasaan kehakiman dilakukan oleh sebuah Mahkamah Agung dan badan peradilan yang berada di bawahnya dalam lingkungan peradilan umum, lingkungan peradilan agama, lingkungan peradilan militer, lingkungan peradilan tata usaha negara, dan oleh sebuah Mahkamah Konstitusi.

Mahkamah Konstitusi sesuai dengan kewenangan yang diberikan dalam UUD 1945 Pasal 24C mempunyai wewenang untuk melakukan pengujian Undang-undang terhadap UUD 1945. Putusan Mahkamah Konstitusi yang mengabulkan uji materiil Undang-undang Perka-

Azhary, Negara Hukum Indonesia, UI Press, Jakarta, 1996, hal 25. winan (UU No.1 Tahun 1974) yang diajukan Hj. Aisyah Mochtar alias Machica binti H. Mochtar Ibrahim yang meminta putranya Muhammad Iqbal Ramadhan bin Moerdiono agar diakui sebagai anak almarhum Moerdiono mantan Menteri Sekretaris Negara di era Soeharto memicu perseteruan antara dirinya dengan keluarga almarhum Moerdiono. ${ }^{7}$

Mahkamah Konstitusi melalui Putusan Nomor 46/PUU-VIII/2010 tanggal 17 Februari 2012, telah melakukan terobosan hukum dengan memutuskan bahwa Pasal 43 ayat (1) UU No. 1 Tahun 1974 tentang Perkawinan bertentangan dengan UUD 1945. Anak luar kawin tidak memiliki hubungan dengan ayahnya. Sebelumnya ketentuan dari UU Perkawinan tersebut menegaskan :8

Anak yang dilahirkan di luar perkawinan hanya mempunyai hubungan perdata dengan ibunya dan keluarga ibunya serta dengan laki-laki sebagai ayahnya yang dapat dibuktikan berdasarkan ilmu pengetahuan dan teknologi dan/atau alat bukti lain menurut hukum mempunyai hubungan darah, termasuk hubungan perdata dengan keluarga ayahnya.

Hasil penelitian terhadap interpretasi hakim terkait anak di luar kawin di Pengadilan Agama Purwokerto, wawancara dengan Drs. Amroni, S.H. M.H. bahwa : Dalam Pasal 43 ayat (1) UndangUndang No. 1 tahun 1974 tentang Perkawinan (UU No. 1 tahun 1974 tentang Perkawinan) diatur bahwa "Anak yang dilahirkan di luar perkawinan hanya mempunyai hubungan perdata dengan ibunya dan keluarga ibunya". Pada 17 Februari 2012, MK menyatakan Pasal 43 ayat (1) UndangUndang Nomor 1 Tahun 1974 tentang Perkawinan

Habiburrahman, Op, Cit, hal 34 . Chatib Rasyid, Op, Cit, hal 182. 
tersebut inkonstitusional bersyarat. Dalam amar putusannya, MK menyatakan Pasal 43 ayat (1) UU Perkawinan tersebut bertentangan dengan UUD 1945 sepanjang dimaknai menghilangkan hubungan dengan laki-laki yang dapat dibuktikan melalui ilmu pengetahuan dan teknologi dan/atau alat bukti lain ternyata mempunyai hubungan darah sebagai ayahnya. Mengenai Putusan MK 46/PUUVIII/2010 tentang Pengujian UU Nomor 1 Tahun 1974 tentang Perkawinan, pasca putusan tersebut hakim khususnya Pengadilan Agama Purwokerto melakukan interpretasi atau penemuan hukum dalam kasus-kasus yang sama terutama dalam status anak di luar nikah. ${ }^{9}$

Menurut penulis, bahwa Pasal 43 ayat (1) UU Nomor 1 Tahun 1974 tentang Perkawinan, yaitu yang berkaitan dengan pencatatan perkawinan dan hubungan hukum anak yang dilahirkan dari perkawinan yang tidak dicatatkan. Anak di luar nikah (hasil nikah sirri) telah mendapatkan perlakuan diskriminatif yaitu dengan dihilangkannya asal-usul dari anak dengan hanya mencantumkan nama ibunya dalam Akta Kelahirannya dan negara telah menghilangkan hak anak untuk kelangsungan hidup, tumbuh dan berkembang karena dengan hanya mempunyai hubungan keperdataan dengan ibunya menyebabkan suaminya tidak mempunyai kewajiban hukum untuk memelihara, mengasuh dan membiayai anak. Tidak ada seorang anakpun yang dilahirkan di muka bumi ini dipersalahkan dan diperlakukan diskriminatif karena cara pernikahan yang ditempuh kedua orang tuanya berbeda tetapi sah menurut ketentuan norma agama. Anak yang sah secara hukum dan wajib diperlakukan sama di hadapan hukum, kenyataannya maksud dan tujuan diundangkannya UU Perkawinan berkaitan pencatatan perkawinan dan anak yang lahir dari sebuah perkawinan yang tidak dicatatkan, dianggap sebagai anak di luar perkawinan sehingga hanya mempunyai hubungan perdata dengan ibunya. Kenyataan ini telah memberikan ketidakpastian secara hukum dan mengganggu serta mengusik perasaan keadilan yang tumbuh dan hidup di masyarakat.

Sebuah perkawinan menurut Pasal 2 ayat (1) Undang-undang Nomor 1 Tahun 1974 tentang Perkawinan adalah sah apabila dilakukan menurut hukum masing-masing agamanya dan kepercayaannya itu, yang dipertegas dalam Penjelasan Pasal 2 Undang-undang Nomor 1 Tahun 1974 tentang Perkawinan tersebut, yakni bahwa "dengan perumusan pada Pasal 2 ayat (1) ini, tidak ada perkawinan diluar hukum masing-masing agamanya dan kepercayaannya itu, sesuai dengan Undang-Undang Dasar 1945. Dimaksud dengan hukum masing-masing agamanya dan kepercayaannya itu termasuk ketentuan perundangundangan yang berlaku bagi golongan agamanya dan kepercayaannya itu sepanjang tidak bertentangan atau tidak ditentukan lain dalam Undang-undang ini”. Ini berarti bahwa jika suatu perkawinan telah memenuhi syarat dan rukun nikah atau ljab Kabul telah dilaksanakan (bagi umat Islam) dan pendeta/pastur/biksu telah melaksanakan pemberkatan atau ritual lainnya (bagi yang non Muslim), maka perkawinan tersebut 
adalah sah, terutama di mata agama dan kepercayaan masyarakat.

Suatu perkawinan yang sah hanyalah perkawinan yang memenuhi syarat-syarat yang ditetapkan dalam Kitab Undang-undang Hukum Perdata (Burgerlijk Wetboek) dan syarat-syarat serta peraturan agama dikesampingkan. Larangan ini termasuk ketertiban umum, artinya apabila dilanggar selalu diancam dengan pembatalan perkawinan yang dilangsungkan itu. Pada asasnya suatu perkawinan harus dibuktikan dengan surat perkawinan. Hanya, apabila daftar-daftar Pencatatan Sipil telah hilang, diserahkan kepada Hakim untuk menerima pembuktian secara lain, asal saja menurut keadaan yang nampak keluar dua orang laki perempuan dapat dipandang sebagai suami istri, atau menurut perkataan undang-undang.

Bahwa inti interpretasi hakim pasca Putusan MK Nomor 46/PUU-VIII/2010 tentang Pengujian UU Nomor 1 Tahun 1974 tentang Perkawinan, di Pe-ngadilan Agama Purwokerto, pengakuan terhadap anak luar kawin, dapat dilakukan dengan:

\section{Pengakuan sukarela}

Pengakuan sukarela yaitu : suatu penga-kuan yang dilakukan oleh seseorang dengan cara yang ditentukan undangundang, bahwa ia adalah bapaknya (ibunya) seorang anak yang telah dilahirkan di luar per-kawinan). Dengan adanya pengakuan, maka timbulah hubungan Perdata antara si anak dan si bapak (ibu) yang telah mengakuinya sebagaimana diatur dalam Pasal 280 KUHPerdata. Pengakuan sukarela dapat dilakukan dengan cara-cara yang ditentukan dalam Pasal 281 KUHPerdata, yaitu :

a. Dalam akta kelahiran si anak Menurut Pasal 281 ayat (1) KUHPerdata, untuk dapat mengakui seorang anak luar kawin bapak atau ibunya dan atau kuasanya berdasarkan kuasa otentik harus menghadap di hadapan pegawai catatan sipil untuk melakukan pengakuan terhadap anak luar kawin tersebut.

b. Pengakuan terhadap anak luar kawin dapat pula dilakukan pada saat perkawinan orang tuanya berlangsung yang dimuat dalam akta perkawinan sebagaimana diatur dalam Pasal 281 ayat (2). Jo Pasal 272 KUHPerdata. Pengakuan ini akan berakibat si anak luar kawin akan menjadi seorang anak sah.

c. Pengakuan terhadap anak luar kawin dapat dilakukan dalam akta oteintik seperti akta notaris sebagaimana diatur dalam Pasal 281 ayat (1) KUHPerdata.

d. Dengan akta yang dibuat oleh pegawai catatan sipil, yang dibutuhkan dalam register kelahiran catatan sipil menurut hari Penanggalannya sebagaimana diatur dalam Pasal 281 ayat (2) KUHPerdata.

\section{Pengakuan Paksaan}

Pengakuan anak luar kawin dapat pula terjadi secara paksaan, yakni dapat dilakukan oleh si anak yang lahir di luar perkawinan itu, dengan cara mengajukan gugatan terhadap bapak atau ibunya kepada Pengadilan Negeri, agar supaya anak luar kawin dalam arti sempit itu diakui sebagai anak bapak atau ibunya, ketentuan ini diatur dalam Pasal 287-289 KUHPerdata. Anak luar kawin yang dapat diakui adalah anak luar kawin dalam arti sempit, yaitu anak yang terlahir dari ibu dan bapak yang tidak terikat perkawinan yang sah baik di antara mereka 
maupun dengan orang lain (tidak tergolong anak zina atau anak sumbang).

Pasal 43 ayat 1 UU Perkawinan dikabulkan karena hubungan anak dengan seorang laki-laki sebagai bapak tidak semata-mata karena adanya ikatan perkawinan, akan tetapi dapat juga didasarkan pada pembuktian adanya hubungan darah antara anak dengan laki-laki tersebut sebagai bapak. Dengan demikian, terlepas dari soal prosedur/admi-nistrasi perkawinannya, anak yang dilahirkan harus mendapat perlindungan hukum. Jika tidak demikian, maka yang dirugikan adalah anak yang dilahirkan di luar perkawinan, padahal anak tersebut tidak berdosa karena kelahirannya di luar kehendaknya.

Konsekuensi hukum terhadap Putusan Mahkamah Konstitusi Nomor 46/PUU-VIII/2010 tentang pengujian UU No. 1 Tahun 1974 di Pengadilan Agama Purwokerto

Konsekuensi putusan MK Nomor 46/PUUVIII/2010 ini, berbeda dengan hukum positif yang selama ini diberlakukan dalam hal keabsahan seorang anak. Undang-undang Nomor 1 Tahun 1974 tentang Perkawinan yang mengatur kedudukan anak luar kawin dalam Pasal 43, yaitu :

a) Anak yang dilahirkan di luar perkawinan hanya mempunyai hubungan perdata dengan ibunya dan keluarga ibunya;

b) Kedudukan anak tersebut ayat (1) di atas selanjutnya akan diatur dalam Peraturan Pemerintah.

Putusan MK 46/PUU-VIII/2010 tentang Pengujian UU Nomor 1 Tahun 1974 tentang Perkawinan merupakan terobosan hukumnya tersebut membuka titik terang hubungan antara anak luar kawin dengan bapaknya. Hubungan darah antara anak dan ayah dalam arti biologis bisa dikukuhkan berdasarkan proses hukum. Membuka kemungkinan hukum untuk subyek hukum (ayah) yang harus bertanggungjawab terhadap anak luar kawin. Subjek hukum tersebut akan bertanggungjawab sebagai bapak biologis dan bapak hukumnya melalui mekanisme hukum dengan menggunakan pembuktian berdasarkan ilmu pengetahuan dan teknologi mutakhir dan/atau hukum.

Dari hasil wawancara dengan Hakim di Pengadilan Agama Purwokerto, sebenarnya konsekuensi hukum pasca Putusan MK Nomor 46/PUU-VIII/2010 tentang Pengujian UU Nomor 1 Tahun 1974 tentang Perkawinan di daerah, khususnya di Pengadilan Agama Purwokerto bahwa: Alasan hukum yang melatar belakangi untuk menegaskan bahwa anak luar kawin pun berhak mendapat perlindungan hukum. Majelis hakim melakukan intepretasi ataupun penafsiran hukum dalam kasus tersebut dan mempunyai pertimbangan hukum yang mendorong adanya keharusan memberi perlindungan dan kepastian hukum yang adil terhadap status seorang anak yang dilahirkan dan hak-hak yang ada padanya, termasuk terhadap anak yang dilahirkan meskipun keabsahan perkawinannya masih disengketakan. ${ }^{10}$

Menurut penulis bahwa pemahaman yang keliru terhadap putusan Mahkamah Konstitusi Nomor 46/PUU-VIII/2010 terutama terhadap kalimat "anak yang dilahirkan di luar perkawinan"

10 Hasil wawancara dengan Drs. H. Syahrial, S.H., hakim Pengadilan Agama Purwokerto, pada tanggal 10 Juli 2014. 
membawa kepada perdebatan panjang. Frasa "di luar perkawinan" sangat berbeda maknanya dengan frasa "tanpa perkawinan". Anak yang dilahirkan di luar perkawinan atau anak yang lahir dari perkawinan yang dilakukan sesuai dengan ketentuan agama dan kepercayaannya tapi tidak tercatat pada KUA atau Kantor Catatan Sipil merupakan anak yang sah secara materiil tapi tidak sah secara formil. Sedangkan anak yang dilahirkan tanpa perkawinan orang tuanya atau anak yang dilahirkan dari hubungan antara lelaki dengan perempuan tanpa adanya ikatan perkawinan merupakan anak yang tidak sah secara materiil juga tidak sah secara formil (anak zina). "Jadi putusan MK ini tidak bisa dihubungkan dengan perzinahan atau akibat perzinahan, kasus yang melatarbelakangi putusan ini hanya berkaitan dengan "pencatatan perkawinan".

Pasal 43 ayat (1) Undang-Undang (UU) Perkawinan Nomor 1 Tahun 1974 sebelum judicial review berbunyi "Anak yang dilahirkan di luar perkawinan hanya mempunyai hubungan perdata dengan ibunya dan keluarga ibunya". Tidak adil ketika hukum menetapkan bahwa anak yang lahir dari suatu kehamilan karena hubungan seksual di luar perkawinan hanya memiliki hubungan dengan perempuan tersebut sebagai ibunya saja. Hal ini menimbulkan ketidakadilan bagi si anak. Anak yang lahir di luar nikah itu posisinya rawan, tidak berdosa. Tapi dalam Pasal 43 ayat (1) UndangUndang Perkawinan Nomor 1 Tahun 1974 anak dan ibunya yang menanggung beban moral, yang seharusnya itu adalah tanggung jawab ayah biologisnya juga. Selain itu, tidak adil pula ketika Pasal 43 ayat (1) tersebut membebaskan laki-laki yang melakukan hubungan seksual yang me- nyebabkan terjadinya kehamilan dan kelahiran anak tersebut dari tanggung jawabnya sebagai seorang bapak dan bersamaan dengan itu hukum meniadakan hak-hak anak terhadap lelaki tersebut sebagai bapaknya. Pokok permasalahan hukum mengenai anak yang dilahirkan di luar perkawinan adalah mengenai makna hukum (legal meaning) frasa "yang dilahirkan di luar perkawinan". Pasal 43 ayat (1) Undang-Undang Perkawinan Nomor 1 Tahun 1974 sebelum uji materi, memberikan pembedaan hukum bagi anak di luar nikah dengan anak dari hasil pernikahan yang sah.

Konsekuensi hukum putusan Mahkamah Konstitusi Nomor 46/PUU-VIII/2010, pemberlakuan norma hukum ini berdampak terhadap status hukum anak yang dilahirkan dari perkawinan Pemohon menjadi anak di luar nikah berdasarkan ketentuan norma hukum dalam Pasal 43 ayat (1) UU Perkawinan. Di sisi lain, perlakuan diskriminatif ini sudah barang tentu menimbulkan permasalahan karena status seorang anak di muka hukum menjadi tidak jelas dan sah. Padahal, dalam UUD 1945 dinyatakan anak terlantar saja, yang status orang-tuanya tidak jelas, dipelihara oleh negara. Tetapi kenyataannya hal yang berbeda diperlakukan terhadap anak pemohon yang dihasilkan dari perkawinan yang sah, sesuai dengan rukun nikah dan norma agama justru dianggap tidak sah oleh UU Perkawinan. Konstitusi Republik Indonesia tidak menghendaki sesuatu yang sudah sesuai dengan norma agama justru 
dianggap melanggar hukum berdasarkan norma hukum. ${ }^{11}$

Pasca Putusan MK Nomor 46/PUUVIII/2010 tentang Pengujian UU Nomor 1 Tahun 1974 tentang Perkawinan, hakim Pengadilan Agama Purwokerto mempunyai intepretasi terhadap keberadaan anak di luar kawin, di Pengadilan Agama ada kasus terkait anak di luar kawin yaitu : Putusan Nomor 1306/Pdt.G/2012/ PA.Pwt, bahwa pasal 43 ayat (1) UU No 1/1974 tentang Perkawinan yang berbunyi "anak yang dilahirkan di luar perkawinan hanya mempunyai hubungan perdata dengan ibunya dan keluarga ibunya", mulai saat ini tidak memiliki kekuatan hukum mengikat. Sepanjang dimaknai menghilangkan hubungan perdata dengan laki-laki yang dapat dibuktikan berdasarkan ilmu pengetahuan dan teknologi dan/atau alat bukti lain menurut hukum ternyata mempunyai hubungan darah sebagai ayahnya. ${ }^{12}$

Menurut penulis, bahwa konsekuensi hukum dari adanya putusan MK tersebut ialah maka diakuinya anak luar kawin (hasil biologis) sebagai anak yang sah berarti akan mempunyai hubungan waris dengan bapak biologisnya tanpa harus didahului dengan pengakuan dan pengesahan, dengan syarat dapat dibuktikan adanya hubungan biologis antara anak dan bapak biologis berdasarkan ilmu pengetahuan, misalnya melalui hasil tes DNA. Namun demikian, apabila ada penyangkalan mengenai anak luar kawin ini dari anak-anak ahli waris yang sah, menurut saya, maka dalam hal ini tetap perlu dimohonkan

11 Hasil wawancara dengan Drs. H. Ariadi,S.H., hakim Pengadilan Agama Purwokerto, pada tanggal 11 Agustus 2014.
Penetapan Pengadilan mengenai status anak luar kawin tersebut sebagai ahli waris yang sah.

Terkait dengan hal di atas, hakim Pengadilan Agama mempunyai penafsiran atau interprestasi tersendiri. Interpretasi atau penafsiran hukum, merupakan metode penemuan hukum yang memberi penjelasan yang gamblang mengenai teks undang-undang agar ruang lingkup kaedah dapat ditetapkan sehubungan dengan peristiwa tertentu. Metode interpretasi ini, adalah sarana atau alat untuk mengetahui makna undangundang. Interpretasi adalah metode penemuan hukum dalam hal peraturannya ada tetapi tidak jelas untuk dapat diterapkan pada peristiwanya.

Para hakim menggunakan pandangan atau kemampuan berdasarkan pemahaman mereka terhadap hukum itu sendiri. Artinya, masingmasing hakim berbeda pula dalam melakukan penafsiran konstitusi, sehingga suatu saat para hakim akan saling bertentangan dalam menafsirkan konstitusi dalam perkara tertentu. Namun, terdapat enam metode interpretasi konstitusi yang diterima luas oleh para pakar sebagaimana dikemukakan oleh Garvey dan Aleinikoff. ${ }^{13}$ Menurut Soedikno Mertokusumo, juga mengemukakan bahwa terdapat metode penemuan hukum melalui penafsiran oleh hakim, ialah : interpretasi gramatikal, interpretasi sitematis atau logis, interpretasi historis, interpretasi teleologis atau sosiologis. Pandangan Soedikno Mertokusumo tersebut umum digunakan dalam kaidah tafsir hukum secara umum. Namun, dalam metode tafsir konstitusi metode interpretasi yang

12 Hasil wawancara dengan Raharjo, S.H., M.Hum., hakim Pengadilan Agama Purwokerto, pada tanggal 14 Juli 2014.

13 Soedikno Mertokusumo, Penemuan Hukum, Sebuah Pengantar, Penerbit Liberty, Yogyakarta, 2001, hal 57. 
digunakan sedikit berbeda walaupun pada intinya penafsiran hukum tersebut dapat pula digunakan untuk itu. ${ }^{14}$

Penafsiran atau interprestasi hakim mengenai anak di luar kawin, bahwa Pasal 43 ayat (1) Undang-Undang (UU) Perkawinan Nomor 1 Tahun 1974 sebelum judicial review berbunyi "Anak yang dilahirkan di luar perkawinan hanya mempunyai hubungan perdata dengan ibunya dan keluarga ibunya". Tidak adil ketika hukum menetapkan bahwa anak yang lahir dari suatu kehamilan karena hubungan seksual di luar perkawinan hanya memiliki hubungan dengan perempuan tersebut sebagai ibunya saja. Hal ini menimbulkan ketidakadilan bagi si anak. Anak yang lahir di luar nikah itu posisinya rawan, tidak berdosa. Tapi dalam Pasal 43 ayat (1) UndangUndang Perkawinan Nomor 1 Tahun 1974 anak dan ibunya yang menanggung beban moral, yang seharusnya itu adalah tanggung jawab ayah biologisnya juga. Selain itu, tidak adil pula ketika Pasal 43 ayat (1) tersebut membebaskan laki-laki yang melakukan hubungan seksual yang menyebabkan terjadinya kehamilan dan kelahiran anak tersebut dari tanggung jawabnya sebagai seorang bapak dan bersamaan dengan itu hukum meniadakan hak-hak anak terhadap lelaki tersebut sebagai bapaknya.

Pokok permasalahan hukum mengenai anak yang dilahirkan di luar perkawinan adalah mengenai makna hukum (legal meaning) frasa "yang dilahirkan di luar perkawinan". Pasal 43 ayat (1) Undang-Undang Perkawinan Nomor 1 Tahun 1974 sebelum uji materi, memberikan pembedaan hukum bagi anak di luar nikah dengan anak dari hasil pernikahan yang sah. Hal tersebut jelas bertentangan dengan Undang-Undang Dasar Negara Republik Indonesia Tahun 1945 Pasal 28B ayat (2).

\section{PENUTUP}

\section{Simpulan}

Bahwa intepretasi hakim pasca Putusan Mahkamah Konstitusi Nomor 46/PUU-VIII/2010 tentang pengujian UU Nomor 1 Tahun 1974 tentang Perkawinan, hakim Pengadilan Agama Purwokerto mempunyai pandangan tersendiri pasca putusan MK tersebut. Pasal 43 ayat (1) Undang-undang Nomor 1 Tahun 1974 tentang Perkawinan diatur bahwa "Anak yang dilahirkan di luar perkawinan hanya mempunyai hubungan perdata dengan ibunya dan keluarga ibunya", anak di luar kawin sepanjang dimaknai menghilangkan hubungan perdata dengan laki-laki yang dapat dibuktikan melalui ilmu pengetahuan dan teknologi dan/atau alat bukti lain ternyata mempunyai hubungan darah sebagai ayahnya. Proses pengakuan anak luar kawin dalam perkawinan sirri dapat dilakukan dengan "pengakuan sukarela" dan "pengakuan paksaan" dari laki-laki yang menjadi ayahnya. Proses pengakuan anak yang dilahirkan dalam perkawinan sirri yang menimbulkan sengketa maka harus dapat dibuktikan kebenaran mengenai laki-laki yang menjadi ayah dari si anak melalui proses peradilan.

1. Konsekuensi hukum terhadap Putusan Mahkamah Konstitusi Nomor 46/PUUVIII/2010 tentang pengujian UU No. 1

\footnotetext{
${ }^{14} \mathrm{Ibid}$, hal 61.
} 
Tahun 1974 di Pengadilan Agama Purwokerto, yaitu tertuang dalam Putusan Nomor 1306/Pdt.G/2012/PA.Pwt, bahwa alasan hukum yang melatarbelakangi putusan tersebut adalah untuk menegaskan bahwa anak luar kawin pun berhak mendapat perlindungan hukum. Majelis Hakim melakukan intepretasi ataupun penafsiran hukum dalam kasus tersebut dan mempunyai pertimbangan hukum yang mendorong adanya keharusan memberi perlindungan dan kepastian hukum yang adil terhadap status seorang anak yang dilahirkan dan hak-hak yang ada padanya, termasuk terhadap anak yang dilahirkan meskipun keabsahan perkawinannya masih disengketakan.

\section{Saran}

Pasca Putusan Mahkamah Konstitusi Nomor 46/PUU-VIII/2010 tentang pengujian UU Nomor 1 Tahun 1974 tentang Perkawinan, hendaknya para hakim dapat menjadikan putusan MK tersebut sebagai pegangan hukum dalam menangani perkara yang berhubungan dengan kasus anak lahir diluar kawin, konsekuensi hukumnya akan dapat memberikan perlindungan hukum dan kepastian hukum yang adil terhadap status seorang anak dan hak-hak yang ada padanya, sehingga anak lahir luar kawin tidak lagi hanya memiliki hubungan perdata dengan ibunya dan keluarga ibunya tetapi juga dengan ayah biologisnya setelah melalui pembuktian yang didukung oleh ilmu pengetahuan dan teknologi atau bukti lain menurut hukum.

\section{DAFTAR PUSTAKA}

Buku :

Azhary, Negara Hukum Indonesia, UI Press, Jakarta, 1996.

Habiburrahman, Anak Luar Nikah Dalam Putusan Mahkamah Konstitusi, Jurnal Mimbar Hukum dan Peradilan, diterbitkan oleh Pusat Pengembangan Hukum Islam dan Masyarakat Madani (PPHIMM), Edisi No.75, Jakarta, 2012.

Mertokusumo, Soedikno, Penemuan Hukum, Sebuah Pengantar, Penerbit Liberty, Yogyakarta, 2001.

Sofyan, Syafran, Analisis Hukum Putusan Mahkamah Konstitusi No. 46/PUUVIII/2010 tentang Status Anak Luar Kawin, tersedia di website http://www. goocom, diakses tanggal 1 Oktober 2013.

Sugiyono, Memahami Penelitian Kualitatif, Alfabeta, Bandung, 2012.

Sunggono, Bambang, Metode Penelitian Kualitatif, Remaja Risda Karya, Bandung, 2006.

\section{Jurnal :}

Rasyid, Chatib, Anak Lahir di Luar Nikah (Secara Hukum) Berbeda Dengan Anak Hasil Zina, ( Putusan Mahkamah Konstitusi No. 46/PUU-VIII/2010), Jurnal Mimbar Hukum dan Peradilan, diterbitkan oleh Pusat Pengembangan Hukum Islam dan Masyarakat Madani (PPHIMM), Edisi No.75, Jakarta, 2012.

\section{Undang-undang:}

Undang-undang Nomor 24 Tahun 2003 tentang MK.

Undang-undang Nomor 1 Tahun 1974 tentang Perkawinan. 